Journal of Social and Development Sciences

Vol. 4, No. 9, pp. 425-434, Sep 2013 (ISSN 2221-1152)

\title{
Policy Initiatives and Agricultural Performance in Post-independent Ghana
}

\author{
*Samuel Asuming-Brempong, John K. M. Kuwornu \\ University of Ghana, Legon, Accra, Ghana \\ *samasum@ug.edu.gh
}

\begin{abstract}
The central role agriculture plays in the development of Ghana's economy has been recognized by several authors, particularly because Ghana's economy is basically agrarian. Nevertheless, the contributions agriculture can make to economic development depend on the policy environment within which agriculture thrives. Several policies, both general and specific to agriculture, which have been pursued under various governments have either promoted or mitigated against the performance of agriculture in Ghana. This paper reviews the various policies under which Ghana's agricultural sector has operated since independence, and provides a synthesis of the major existing policies and recent changes and how these have affected the agricultural sector. The analysis shows that the socialist model of the 1960s contrasted sharply with the liberalized market approach of the 1980s and 1990s, particularly under structural adjustment. These differing policy orientations have had significant effects on agricultural performance in Ghana, and the roles of agriculture at different periods. For instance, the policy effects of agricultural activities on the environment, such as the promotion of export commodities, the exploitation of timber and for est resources, mining, and indiscriminate sale and use of agro-chemicals in Ghana have been negative. On the other hand, promotion of cash and export crops through government policy incentives have improved rural incomes for farmers that cultivate such crops, and helped to reduce poverty among this group. In general, the policy effects on agriculture in Ghana have been mixed.
\end{abstract}

Key Words: Agriculture, policies, forest resources, liberalization, policy effects

\section{Introduction}

The agricultural sector is expected to continue to play a major role in Ghana's economic growth and development in the short to medium term. Its importance is by virtue of the contributions the sector makes to several important economic variables. It contributes the highest proportion to gross domestic product (GDP), an average of about $40 \%$ since the mid-1990s. Agriculture offers job avenues to the highest proportion of the economically active population mainly farmers, farm labourers, and other workers in agricultural related activities. It is estimated that the sector employs about $60 \%$ of Ghana's active labour force. Agriculture contributes substantially to government revenue mainly through duties paid on the export of agricultural commodities, especially cocoa; and it has been the major contributor to Ghana's foreign exchange earnings for several years. This role has been performed through exports of agricultural commodities and conservation of foreign exchange by producing import-substituting food and raw materials. Between 1999 and 2002 for example, the agricultural sector contributed $38.5 \%, 35.4 \%, 33.9 \%$, and $35.5 \%$, respectively, to the country's foreign exchange earnings. This pattern has continued in the 2000s. Another important role played by the agricultural sector is the provision of food for the large non-agricultural and mainly urban population. This segment of the population is now expanding rather fast, at a rate of about $3.2 \%$ per annum, and also acquiring new tastes and demanding diversified food products. The country has been self-sufficient or nearly so in the production of several food commodities, particularly roots and tubers, plantain, fresh fruits and vegetables, and some cereals such as maize, sorghum and millet. Furthermore, the sector provides raw materials (cocoa, cotton, palm oil, etc.) for some of the agro-based industries in the country, and for export. After a persistent decline of the economy during the 1970s, an economic recovery programme (ERP) and related structural adjustment programme (SAP) embarked upon by the government with the assistance of the Breton Woods institutions reversed the declining trend. However, agricultural growth has been rather unstable over the 1984-2000 periods. The paper provides a review of Ghana's agricultural development process since independence in 1957, making reference to the key development issues during the colonial era. A historical survey of various economic and agricultural policies pursued by various governments and how they have 
affected agriculture is presented. The rest of the paper is structured as follows: Section 2 presents specific economic policies that have directly affected agricultural performance. Section 3 presents policy effects on various roles of agriculture. Section 4 provides the conclusions.

\section{Economic Policies that have directly affected Agricultural performance in Ghana}

There are several economic reforms launched in 1983, coupled with exogenous factors, that have exerted some effects on the economy of Ghana, including the level and composition of aggregate real output, sectoral real output, inflation, unemployment, balance of payments, savings and investment, national income, agriculture, and the environment. This section discusses specific policies that have had significant effects on the performance of the agriculture and the sector. Subsequently, the policy effects on various roles of agriculture in the context of the Ghanaian economy are highlighted.

1) Historical Overview of Agricultural Policies in Ghana: As evidenced from the development plans discussed in earlier sections, Ghana's agricultural policies during the pre-independence colonial era were largely biased towards the promotion of mainly industrial crops for export, particularly cocoa and oil palm. The focus of policy was to make the then Gold Coast a source of industrial raw materials for the manufacturing industries in Europe, and on the other hand a market for manufactured goods from the West. A poll tax law, which the colonial administration passed at the beginning of the twentieth century in particular, caused most peasant farmers to move into cash crop production, mainly cocoa. The agricultural sector had been dominated by smallholder farmers, and in response to the economic opportunities, these transformed Ghana into the world's leader in cocoa production from 1911. The colonial government, in order to facilitate the exploitation of the valuable wealth particularly of southern Ghana, embarked on infrastructure development, mainly roads and railways. By the time of independence in 1957, Ghana's export led-growth had made it a more prosperous country compared to the other countries in West Africa.

A major policy focus of the government after independence was the modernization of agriculture. The traditional subsistence system of agricultural production was considered obsolete, and incapable of being modernized and adapted to the needs of an expanding economy. The government established the Agricultural Development Corporation (ADC) to spearhead the modernization of agriculture by way of large-scale production with massive government investments. Particularly from 1961, the state intervention in agricultural production assumed ideological dimensions being socialist oriented, but the performance of these large-scale units was rather disappointing. When the socialist government of Nkrumah was overthrown in 1966, the military as well as the subsequent civilian government that immediately followed adopted a policy of capitalist development of agriculture. To facilitate the activities of the many smallholder farmers who dominate Ghana's agriculture, the government established single commodity development boards, such as for cotton and grains. The Agricultural Development Bank (ADB) was so named in 1968 to support and provide needed credit to promote agriculture. The ADB was established as a Development Bank by an Act of Parliament (Act 286) in 1965 under the name Agricultural Credit and Cooperative Bank before its name was later changed.

In addition, government made substantial investments in rural development schemes (e.g. roads, water, electricity) to encourage rural people to stay on their farms and discourage rural-urban migration. This policy was not sustained during the 1970s by the governments that followed, and agricultural production declined steadily until the Economic Recovery Programme (ERP)/Structural Adjustment Programme (SAP) that began in 1983, with varied policy packages including those for agriculture. Several policies were initiated between the period after independence and the early 1980s, which had direct effect on agriculture. Subsequent to the establishment of state farms (which could not be sustained), a rural development programme that targeted rural infrastructure development and the promotion of agriculture was implemented (1969-1972). Then came the "Operation feed yourself" and "Operation feed your industries" drive promoted by the government (1972-1974) as a way of increasing agricultural production and providing needed raw materials for industries most of which operated at very low capacities. Price controls for manufactured goods were introduced, and guaranteed minimum prices set by government for major agricultural commodities, notably cocoa, maize and rice. However, agriculture was heavily taxed during the period, which together with other 
factors such as adverse weather conditions and low commodity prices resulted in a continual decline in agricultural production.

2) Market Liberalization: Agriculture was a natural target of intervention under the ERP/SAP since it is the largest sector of Ghana's economy. A major policy focus for the agricultural sector was the deregulation of both the input and output markets. Administered prices for selected agricultural commodities affected the agricultural product market. Subsidies for essential inputs such as fertilizers and other agro-chemicals in previous years had led to serious bottlenecks in the availability and timely delivery of these inputs, and seriously affecting agricultural productivity. These subsidies were therefore gradually removed, and the importation and sale of these inputs privatized to promote efficiency. However, the resultant high cost of inputs (such as fertilizer) adversely affected agricultural productivity. Similarly, guaranteed prices, which existed for maize and rice, were discontinued, and the output market liberalized to allow imports to freely compete with domestic products. By the end of the 1980s, only cocoa continued to enjoy a guaranteed price because of the unique position it occupies in the Ghanaian economy, even though its internal marketing has largely been deregulated to promote efficiency. As already indicated, the effect of the liberalization of the agricultural markets on both the aggregate and individual commodity output has been mixed, and more effort is needed to ensure that the efficiency envisaged by the policy reforms is achieved in the sector.

Following Leith (1970) and Aneani (1995) we adopted the log-variance instability index specified in equation (1) as:

$I_{x}=$ Anti $\log o f\left[\frac{\sum\left(\log P_{t} / P_{t-1}\right)-\left(\log P_{t} / P_{t-1}\right)^{2}}{N-1}\right]^{1 / 2}$

$I_{x}$ is the index of price stability of the commodity, $P_{t}$ and $P_{t-1}$ are the current and one year lagged price of the commodity respectively.

The results presented in Table 1 show that for the major food products, the post-liberalization era registered higher price instability than the pre-liberalization era, except for yam. For example, the instability index of maize was 8.31 for pre-liberalization era and 17.43 for post-liberalization era. The implication is that food prices have been more volatile during the market liberalization period. These results are confirmed by the Coefficient of variations of the various commodities under the Pre-Liberalization and Post-Liberalization periods. The Coefficient of variation, being a dimensionless measure of volatility in variables has been applied in numerous studies (e.g., Kuwornu et al., 2009).

Table 1: Estimates of Food Price Instability Measurements

\begin{tabular}{|c|c|c|c|c|c|}
\hline \multirow[t]{2}{*}{ Commodity } & \multicolumn{3}{|c|}{ Pre-Liberalization period } & \multicolumn{2}{|c|}{ Post-Liberalization period } \\
\hline & $\begin{array}{ll}\text { Coefficient } & \text { of } \\
\text { Variation (CV) } & \\
\end{array}$ & $\begin{array}{l}\text { Instability } \\
\left(I_{x}\right)\end{array}$ & Index & $\begin{array}{l}\text { Coefficient } \\
\text { Variation (CV) }\end{array}$ & Instability Index $\left(I_{x}\right)$ \\
\hline Maize & 19.56 & 8.31 & & 36.48 & 17.43 \\
\hline Rice & 24.54 & 10.21 & & 37.68 & 18.21 \\
\hline Millet & 18.07 & 8.01 & & 30.31 & 15.28 \\
\hline Sorghum & 20.10 & 9.13 & & 40.71 & 19.45 \\
\hline Yam & 16.94 & 7.94 & & 24.23 & 9.81 \\
\hline Cassava & 25.23 & 10.48 & & 47.70 & 19.53 \\
\hline Plantain & 26.46 & 11.03 & & 25.97 & 10.12 \\
\hline
\end{tabular}

Source: Authors' Computation

3) Internal Marketing of Cocoa: Falling world price of cocoa, inefficiencies in the internal marketing under the COCOBOD, and high levels of taxation of the crop over the years have given rise to low producer prices, dis-investment and declining cocoa yields and output in Ghana. Massive devaluation of the local currency (i.e., the cedi), since the ERP period has helped to increase the nominal cocoa producer prices, and farmers have responded by increasing output. Output figures for the 2002/2003 year indicate that cocoa output reached the 500,000 mt mark in response to higher nominal producer prices and mass spraying of cocoa farms (against pests and diseases) embarked upon by the government. Indications are that improved incentives for local cocoa farmers will have to come from reduced government reliance on cocoa export levy, and a greater 
efficiency in the internal marketing of cocoa. Competition in the internal marketing of cocoa should promote increased marketing efficiency and higher producer prices as buyers compete for the crop. To this end, two new buyers, Universal Crop Protection (UCP) Ltd and Cashew and Spices Products, were licensed towards the end of 1992 to buy cocoa alongside the Produce Buying Company (PBC), a subsidiary of the COCOBOD. Subsequently, more cocoa buying agencies have been licensed. This introduced some level of competition into the internal purchasing of dry cocoa beans in Ghana.

4) Agricultural Services Rehabilitation Project (ASRP): Following the commencement of the ERP in 1983, the ASRP (1987-1990) was the first integrated intervention in the agricultural sector. The objectives were to (i) strengthen the institutional capacity and services of the Ministry of Food and Agriculture, and (ii) to support policy reforms involving the privatization of certain services (including fertilizer marketing, tractor services, and supply of veterinary drugs). Prior to the ASRP, a one-crop project, the Oil Palm Development Project (OPCP) - Phase II (1984-88) had already commenced to support diversification away from cocoa and for import substitution. Also, three other projects were initiated in the 1980s to support reforms in the agricultural sector, namely: Cocoa Rehabilitation Project (CRP) (1988-1999) to boost cocoa production; Forestry Resource Management Project (FRMP) (1989-1992) to improve management of industrial forestry production and promote conservation and tree planting; and Rural Finance Project (RFP) (1989-1992) to implement a financial restructuring programme for rural banks and build local capacity for rural finance policy. The main effect of these projects was to reverse the declining trend in agricultural production experienced in the late 1970 s to the early 1980 s.

5) Medium Term Agricultural Development Programme (MTADP): The need for a comprehensive framework for the recovery and accelerated growth of the agricultural sector informed the initiation of the MTADP. The objective was to define a programme of policy and institutional reforms, and a complementary set of investments needed to achieve a higher growth rate in agriculture. The programmes set out in the MTADP (1991-2000) aimed at a sustained annual growth in agricultural GDP of about 4\%. The policy reforms focused on the incentive framework for agricultural production, trade and processing. The MTADP proposed an increase in private participation in agricultural marketing, a more free market pricing, and the liberalization of supply of seed, fertilizer and other agricultural inputs. The freeing of trade was expected to reduce marketing costs, raise producer prices and stimulate investment in processing; and the privatization of input supply was to improve the reliability of supply through competition. There has been good progress over the past years resulting from the implementation of MTADP as is evident from the substantial and sustained resurgence of food crop production by Ghana's two million smallholder farmers. Food production kept well ahead of population growth, during 1994-1997, with positive effects on rural and overall income, nutrition and poverty levels. The performance of traditional export and industrial crops was less positive, while non-traditional agricultural exports have shown remarkable growth, especially fruits and vegetables. Between 1991 and 1997 the export of pineapples increased by over 200\%, cassava output quadrupled, and maize production also tripled. Cocoa production rose at an annual average rate of $4.3 \%$. Livestock and fisheries production, however, remained stagnant.

The MTADP served as a main policy document for the Ministry of Food and Agriculture (MoFA) during the 1990 s, and from it emerged various programmes and projects (with funding from the World Bank mainly) for improving the agricultural sector. These included Agricultural Diversification Project (ADP) (1991-1999), National Agricultural Research Project (NARP) (1991-1999), National Agricultural Extension Project (NAEP) (1992-2000), Agricultural Sector Adjustment Credit (ASAC) (1992-1999), National Livestock Services Project (NLSP) (1993-1999), Agricultural Sector Investment Project (ASIP) (1994-2000), Fisheries Capacity Building Project (FCBP) (commenced in 1995), among others. Building on the achievements of the MTADP, the Accelerated Agricultural Development Strategy (AAGDS) was prepared in 1996 to enhance agricultural growth. One of the strategies under AAGDS to facilitate the transformation of the agricultural sector was the Agricultural Services Sub-sector Investment Project (AgSSIP), whose implementation commenced in 2002. Subsequent to that, MoFA prepared the Food and Agriculture Sector Development Policy I (FASDEP I) document (2002), which was revised in 2007. The FASDEP II adopts the sector-wide approach to managing agricultural development and provides a broad framework for agricultural development in Ghana. Also, some commodity specific programmes were initiated by the Kufuor government since 2001, called President's 
Special Initiatives (PSIs), one of which targeted cassava for processing into starch for export, and another targeted oil palm production, among others.

Other related programmes initiated in the 1990s that have impacted agriculture either directly or indirectly include the National Feeder Roads Project (NFRP), Coastal Wetlands Management Project (GEF), Environmental Resource Management Project (MRMP), Financial Sector Adjustment Programme (FINSAP), Village Infrastructure Project (VIP), Programme of Actions to Mitigate the Social Cost of Adjustment (PAMSCAD), and Minimum Wage increments. In the 2000s the new administration of the New Patriotic Party (NPP) developed and relied more on poverty reduction papers (PRPs) with donor support, namely: Ghana Poverty Reduction Strategy I (GPRS I) and Growth and Poverty Reduction Strategy II (GPRS II); while at the end of the decade the National Democratic Congress (NDC) that came into government has developed and are guided by the Medium Term Agriculture Sector Investment Plan (METASIP, 2011-2015).

a) Agricultural Diversification Project (ADP): The objective of the ADP was to revitalize and expand the cultivation and export of non-cocoa tree crops (oil palm, coffee and rubber) and horticultural crops (mainly pineapples) for import substitution and to reduce the country's reliance on cocoa. The project provided training and technical support to farmers as well as the institutions that were involved in the production of the target crops. The performance of all the target crops improved under the project.

b) National Agricultural Research Project (NARP): The broad objectives of the strategic plan under the NARP were to ensure that agricultural research priorities in Ghana are consistent with national agricultural policy, as well as address farmers' needs so as to ensure a sustainable use of the resources of the country. These included initiating a long-term process to strengthen the country's agricultural research systems in order to generate improved technologies, and to contribute to national development. The strategic plan embraced all agricultural research activities in the country and was designed around some important components. The first component was institutional building with the emphasis on research management, human resources development, rehabilitation of research facilities, and improvement in library and information systems. The second was financial resources development and sustainability. Financial resources for agricultural research in Ghana have come mainly from government sources and donors. This has been sometimes erratic, inadequate and unpredictable. Under the strategic plan all donors' contributions were to be routed through the National Agricultural Research Committee (NARC), and a consolidated funding mechanism developed. Other potential funding sources, including a research development fund from donations, were also explored.

c) National Agricultural Extension Project (NAEP): The NAEP, which was in its mid-term of implementation in 1995, recorded achievements, especially in the training of staff. Such success, without doubt, helped to re-align project implementation. The training activities involved both the front line staff (FLS) and subject matter specialist (SMS) of MoFA and other allied institutions. The Extension Agent to Farmer ratio which stood at 1:1,504 in 1991 improved to $1: 780$ by 2000.

d) Agricultural Sector Adjustment Credit (ASAC): The ASAC provided support for reforms in the agricultural sector, and targeted poverty reduction as a major area of concern since most of the poor in Ghana are found among food crop farmers who live in rural areas. For example, the ASAC requested the government of Ghana to identify and fund poverty reduction programs in its 1992 and 1993 budgets.

e) Smallholder Credit, Input Supply and Marketing Project (SCIMP): A related program to the ASAC was the Smallholder Credit, Input Supply and Marketing Project (SCIMP), which was implemented in the Ashanti, Brong-Ahafo and Volta Regions of Ghana between 1990 and 1999. The scheme focused on assisting farmers and food traders by providing short-term loans to support their economic activities. In addition, the project also assisted many farming communities in the construction of dams and hand-dug wells for both agriculture and household use; and provided financial support for the Department of Feeder Roads (DFR) to improve some $114 \mathrm{~km}$ of farm access roads in order to reduce marketing problems.

f) National Livestock Services Project (NLSP): The objectives of the NSLP included increasing meat, egg and milk production, improvements in smallholder incomes, and a reduction of the financial burden on the 
government for services provided to the livestock sub-sector. It also sought to develop and train a number of community health workers to facilitate the privatization of veterinary services, both of which achieved only some limited successes. Its impact on the overall livestock production in the country has been minimal.

g) Agricultural Sector Investment Project (ASIP): The main objective of ASIP was to increase the flow of resources, both technical and financial, for rural development so as to increase agricultural productivity and access to markets. The ASIP was to provide support for community or group investments in infrastructure in rural areas. It was aimed at providing some of the needed incentives for increased agricultural production and thereby enhance incomes and reduce poverty. The project provided assistance to the agro processing industry, development of market infrastructure (including storage facilities), rehabilitation and maintenance of rural feeder roads, and provision of water in rural areas.

H) Land Conservation and Smallholder Rehabilitation Project (LACOSREP): The LACOSREP (1991-1997) targeted mainly retiring civil and public sector employees who had interest in going into farming. In addition to providing credit to these farmers, they were trained in proper tillage methods. Small dams were rehabilitated, and lands at their farm sites were also bonded for improved water management.

i) Fisheries Capacity Building Project (FCBP): The FCBP commenced in 1995 and is still ongoing. The objective has been aquaculture development to supplement sea and fresh water fishing in the country. Various training programmes have been implemented, and farmers assisted to develop fish-farming in several communities. The impact on fish production, though, has been modest so far.

j) Accelerated Agricultural Development Strategy (AAGDS): The AAGDS was prepared in 1996 as a follow-up to the MTADP to enhance agricultural growth in Ghana. It was the main policy document that outlined the strategies to transform the agricultural sector. There were five key elements under the AAGDS, namely: (i) promotion of selected products through improved access to markets, (ii) development of, and improved access to technology for sustainable natural resource management, (iii) improved access to agricultural financial services, (iv) improved rural infrastructure, and (v) enhanced human resource and institutional capacity.

k) Food and Agriculture Sector Development Policy (FASDEP): This policy document was prepared by MoFA in 2002 and revised in 2007, FASDEP adopts the sector-wide approach (rather than the discrete project approach pursued in the past) to managing agricultural development, and provides a broad framework for agricultural development in Ghana. It is the main policy document of MoFA, and detailed projects and programme implementation plans and activities have been developed from it to deal with specific issues in agriculture.

1) Financial Sector Adjustment Programme (FINSAP): In order to solve the problems and reverse the economic decline and resume growth, Ghana commenced an intensive financial sector adjustment strategy with assistance of the IMF and the World Bank in 1988. The financial sector adjustment programme was implemented in order to enhance the effectiveness of the implementation of the Structural Adjustment Programme (SAP) in addressing the prevailing structural and institutional weaknesses of the financial sector. Financial sector reforms aimed to improve the efficiency of intermediation and the use of resources, including the allocation of investment. The reforms attempted to reduce distortions in credit allocation, typically in part through the removal of controls on interest rates, with the intention of allowing them to become market determined. In addition, appropriate information and prudential supervision system was put in place. As part of the broader structural reform in the financial sector of the economy, the Bank of Ghana (BOG) between 1989 and 1991, under the Rural Finance Project restructured rural banks with financial support from the World Bank.

Until 1991, credit policy in Ghana was aimed at directing credit to priority sectors including agriculture; and it was mandatory for banks to allocate at least $20 \%$ of their loans to agriculture. Interest rates on loans to agriculture were not only fixed by the Central Bank, but the rates were set at about 2\%-3\% below other rates. Such government controls as mandatory credit ceilings were completely removed under FINSAP. It is sometimes alleged that FINSAP has induced significant efficiency in credit mobilisation and allocation. 
However, Aryeetey (1996) emphasised that the declining trend of credit allocation to priority areas including the agricultural sector has not changed even after the reform. Furthermore, available data revealed that total commercial and secondary banks' loans and advances to agriculture declined from $15.9 \%$ of the aggregate total loans in 1990 to $5.7 \%$ in 1995, creating the situation of inadequate supply of agricultural finance from the formal banking sector (MOFA, 1997). The figure increased steadily to $12.2 \%$ in 1998 and by 1999, it had dipped again to $11.8 \%$ (ISSER, 2000). In 2001, allocation of credit to agriculture had declined further to $9.6 \%$. Over the period 1986 to 1996, loans and advances from rural banks to agriculture also declined from $36 \%$ to $13 \%$, before increasing again to $17 \%$ in 2001 .

m) Village Infrastructure Project (VIP): The objective was to enhance the quality of life of rural people through increased transfer of technologies and financial resources to develop and sustain basic village infrastructure. The project focused on the development of four main areas, namely rural water, rural transport, rural post-harvest activities, and strengthening of rural institutions. Its impact on agriculture and the rural communities has been substantial.

N) Programme of Actions to Mitigate the Social Cost of Adjustment (PAMSCAD): The PAMSCAD was an inter-sectoral initiative developed towards the end of the 1980s when there were serious complains about the adverse effects of the economic reform processes on the rural poor and other most vulnerable groups in society, such as women and children. It included mainly donor-funded community initiated development projects aimed at reducing the adverse effects of the reforms, as well as projects on education, employment generation, and special projects to provide some assistance to retrenched civil servants and other workers. Its rural focus made it directly affect the agricultural communities in the areas where they were implemented, even though its impact was in doubt since funding was limiting, and project selection was problematic and sometimes unduly politicized. A component of PAMSCAD, which focused on women dubbed Enhancing Opportunities for Women in Development (ENOWID), was largely successful because it was well prepared and effectively implemented as it enjoyed substantial support from donors, and therefore had positive impact on many rural women and farmers. Similarly, the water and sanitation component was also largely successful, improving the lot of the rural communities, which also improved their agricultural productivity.

\section{Policy effects on various roles of Agriculture}

The dominance of the economy of Ghana by the agricultural sector due to its relative size and the various roles it plays also translate into significant effects that the sector exhibits on the entire economy in response to policy and other reforms. Based on available information in the literature and analysis done under the roles of agriculture (ROA) project (FAO, 2004), an assessment of the policy effects on the various roles of agriculture, particularly during the 1990s, has been attempted in this section. These are presented in Table 2.

1) Environmental Role: Agricultural activities such as the use of traditional tools and the practice of "slash and burn" by most smallholder farmers in Ghana create both positive and negative externalities. The positive externalities include soil conservation, water retention, ground water recharge and flood prevention, agricultural biodiversity conservation (including wildlife and wild species), reduction in green house gas emissions and carbon sequestration, and rural amenities preservation (such as landscape). On the negative side, clearing of the forest vegetation enhances deforestation and loss of biodiversity; also the burning of the vegetation exposes the soil to the effects of the sun and torrential rains leading to soil erosion, as well as promote green gas emissions locally. In addition, there is the pollution of water bodies as a result of indiscriminate use of chemicals, and extensive farming particularly on marginal lands results in land degradation at various levels. As already discussed above, the policy effects of agricultural activities on the environment, such as the promotion of export commodities, the exploitation of timber and forest resources, mining activities, and indiscriminate sale and use of agro-chemicals in Ghana have been negative in many respects. However, trade liberalization and agricultural subsidy removal have limited the use of improved agricultural technologies (for example, high fertilizer prices have increased production cost), and subsequently worsened the extent of soil degradation.

2) Poverty Alleviation Role: Poverty in Ghana has been characterized as a rural phenomenon (e.g., Kuwornu et al., 2013). This implies that the majority of the poor in Ghana are found in the rural areas, particularly 
among food crop farmers, even though the urban poor are also common. Since agriculture is the major occupation of a majority of the rural population, any intervention in agriculture and their subsequent effects on agricultural incomes and income distribution can have profound effect on poverty alleviation among the rural folk. For example, the promotion of cash and export crops through government policy incentives have improved rural incomes for farmers that cultivate such crops, as in the case of cocoa which has received continuous increases in the producer price since economic reforms in the 1980s. Evidence from the Ghana Living Standards Surveys (GLSS) conducted in 1991/92 and 1998/99 shows that the percentage of Ghanaians falling below the poverty line of 900,000 Cedis per annum (i.e., 90 Ghana Cedis) fell from 52\% in 1991/92 to about 40\% in 1998/99, with most of the decline occurring in Accra and the forest agro-ecological zone where cocoa is produced. But poverty increased during the same period in the savannah zone where there is a high concentration of food crop farmers. On the other hand, both forest reserves and marginal lands have come under severe pressure in the cocoa growing areas because of the attempt by farmers to expand their farm, which has invariably led to deforestation and land degradation in some areas. Similarly, increase of unskilled labour wages in the rural areas through increases in smallholder incomes, lower food prices through higher agricultural output resulting from price incentives, and forward and backward linkages which stimulate nonfarm income growth and investment in agro-industries in Ghana have had positive effect on reducing poverty.

3) Food Security Role: Achieving food security in Ghana faced many constraints, including unstable domestic production, whether the country has the capacity to import to make up for the shortfalls in domestic production, high food prices, low income of households, persistent high level of unemployment, and the difficulty faced by many households in meeting the daily adequate and nutritious food needs. Effectively addressing these constraints so as to achieve security in the country has been elusive. However, the role of agriculture to supply adequate food for the rapidly increasing population has remained high on the agenda of governments for addressing the food security problem in the country. Government policy has focused on food security during most of the 1980s and 1990s, and under a new government since 2001 this has been further buttressed by more emphasis on food self-sufficiency in food products such as cereals and starchy staples (maize, roots and tubers, etc) in which the country has comparative advantage. In addition, import substitution through vigorous domestic production for some emerging staples such as rice has become an important policy issue in the recent past. This implies that the promotion of food production could improve the ability of Ghanaian farmers to feed the growing population and increase their incomes, but at the same time generate externalities as more lands are brought into cultivation.

4) Buffer Role: The buffer role of agriculture may be broadly defined as the sector's ability to absorb increases in urban unemployment (i.e. a form of unemployment insurance) resulting from internal and external economic shocks, such as the labour retrenched during the economic reforms under structural adjustment. The ability of agriculture to play this buffer role has hinged on the peculiarities of Ghana's agriculture and its performance, such as the dominance of small-scale farmers and land tenure arrangements, which provides natives relatively easy access to family lands (even though for non-natives this could be a major drawback in some areas). The country experienced a worsening in poverty indicators and decline in access to health, education and other social services across all social classes with the poor particularly hardest hit as massive re-deployment/retrenchment of labour from the public sector was undertaken during reforms in the 1980s. This period, especially the mid to late 1980s, saw periodic but significant reverse migration flows from urban (non-agricultural) back to rural (agricultural) areas. Agriculture thus provided the urban skilled and un-skilled retrenched labour a buffer against sudden deterioration in their living standards. The policy impact of this buffer role could be enormous, considering the relatively large numbers of public sector retrenched workers.

5) Social Viability Role: The social viability role of agriculture in Ghana has manifested itself primarily in agricultural population re-distribution as farmers chased emerging opportunities across ecological zones (e.g. new frontiers for the cultivation of cocoa and other non-traditional export crops). On the one hand, rural urban migration seems to have been on the increase. The 2000 Population and Housing census shows the country's urban population as standing at about 38\%, having increased from $34 \%$ in the previous census of 1984. Similarly, the population of the nation's capital, Accra, which was growing at the rate of $3.3 \%$ according to the 1984 census, is now growing at 4.4\% (2000 Census). These may be compared with the national population growth rates of $2.6 \%$ and $2.5 \%$ for 1984 and 2000 , respectively. The social cost of the fast 
growing urban areas manifests itself in many social vices including armed robbery, prostitution and a growing number of homeless youth. In addition, the pressure on available but limited social services has been enormous.

Table 2: Policies/Instruments/Strategies and their Effects on the Roles of Agriculture

\begin{tabular}{|c|c|c|c|c|c|c|}
\hline Policies/ & Roles of $A$ & culture & & & & \\
\hline $\begin{array}{l}\text { Instruments/ } \\
\text { Strategies }\end{array}$ & $\begin{array}{l}\text { Environ- } \\
\text { ment }\end{array}$ & Poverty & $\begin{array}{l}\text { Food } \\
\text { Security }\end{array}$ & Buffer & $\begin{array}{l}\text { Social } \\
\text { Viability }\end{array}$ & Culture \\
\hline Market Liberalization & $+/-$ & $+/-$ & $+/-$ & $+/-$ & $+/-$ & $+/-$ \\
\hline - $\quad$ Price Deregulation & + & + & + & + & + & + \\
\hline Subsidy Removal & - & - & - & - & - & - \\
\hline - $\quad$ Input Supply Privatisation & - & - & + & + & + & + \\
\hline Internal Marketing of Cocoa & - & + & + & + & + & + \\
\hline - Guaranteed Price & - & + & + & + & + & + \\
\hline - $\quad$ More Private Agencies & - & - & + & + & + & + \\
\hline $\begin{array}{l}\text { Medium Term Agricultural Development } \\
\text { Programme (MTADP) }\end{array}$ & + & + & + & + & + & + \\
\hline $\begin{array}{l}\text { Agricultural Diversification } \\
\text { Project (ADP) }\end{array}$ & - & + & + & + & + & + \\
\hline $\begin{array}{l}\text { National Agricultural Research } \\
\text { Project (NARP) }\end{array}$ & + & + & + & + & + & + \\
\hline $\begin{array}{l}\text { National Agricultural } \\
\text { Programme (NAEP) }\end{array}$ & + & - & - & $+/-$ & $+/-$ & + \\
\hline $\begin{array}{l}\text { National Livestock Services } \\
\text { Project (NLSP) }\end{array}$ & + & + & + & + & + & + \\
\hline $\begin{array}{l}\text { Agricultural Sector Investment } \\
\text { Project (ASIP) }\end{array}$ & $+/-$ & + & + & + & + & + \\
\hline $\begin{array}{l}\text { Fisheries Capacity Building } \\
\text { Project (FCBP) }\end{array}$ & + & + & + & + & + & + \\
\hline $\begin{array}{l}\text { Financial Sector Adjustment Programme } \\
\text { (FINSAP) }\end{array}$ & $+/-$ & + & + & + & - & - \\
\hline Village Infrastructure Project (VIP) & $+/-$ & + & + & + & + & + \\
\hline $\begin{array}{l}\text { Environmental Resource } \\
\text { Management Project (MRMP) }\end{array}$ & + & - & - & - & - & - \\
\hline $\begin{array}{l}\text { Programme of Actions to Mitigate } \\
\text { the Social Cost of Adjustment (PAMSCAD) }\end{array}$ & + & + & + & + & + & + \\
\hline $\begin{array}{l}\text { Accelerated Agricultural Development } \\
\text { Strategy (AAGDS) }\end{array}$ & - & + & + & + & + & + \\
\hline $\begin{array}{l}\text { Agricultural Services } \quad \text { Sub-sector } \\
\text { Investment Programme (AgSSIP) }\end{array}$ & + & + & + & + & + & + \\
\hline $\begin{array}{l}\text { Food \& Agriculture Sector Development } \\
\text { Policy (FASDEP) }\end{array}$ & + & + & + & + & + & + \\
\hline National Feeder Roads Project (NFRP) & - & + & + & + & + & + \\
\hline Minimum Wage Increases & + & + & + & + & - & - \\
\hline
\end{tabular}

Note: (+) means positive effect; (-) means negative effect.

On the other hand, the policy of diversification of the agricultural system by encouraging people to go into the cultivation of non-traditional export crops is one way of trying to reverse the rural urban drift. Already the non-traditional export crop sub-sector is making a steady contribution to the country's foreign exchange earnings, and it is believed that some of the benefits will accrue to the members of the communities in which these crops are produced, and eventually enhance their social viability. This appears to be happening in the case of the Northern Region of Ghana, which has changed from a net loss to a net gain of population since rice production was intensified there from the late 1970s. The 1984 and 2000 censuses show that the population of the largely rural region has been growing at $3.4 \%$ and $2.9 \%$, respectively, over and above the national respective averages of $2.6 \%$ and $2.5 \%$. As a consequence of new agricultural opportunities, itinerant trading involving the movement of products from one ecological region to another has been an important feature of the process. Agricultural commodities have dominated itinerant trading in Ghana, involving the transportation of tubers, legumes and grains from the savannah north, and plantains, roots, fruits and 
vegetables from the forest south to the urban centres. The social cohesion fostered through these activities constitutes some of the direct and indirect roles of agriculture.

6) Cultural and Perception Role: The contributions made by agriculture and the rural world in shaping the national culture, and the interpretations various ethnic groups place on various phenomenon, constitute a significant component of the role played by agriculture in the cultural evolution of Ghana. For example, agriculture in Ghana has been largely considered as a way of life particularly for the rural dwellers, rather than as a business. Consequently, traditional practices and social norms have made agriculture generally a "non-enviable" activity compared to other professions, and many people consider agriculture as "the last resort" when all others have failed. The extent to which policy has impacted some of these traditions and social norms to provide socio-economic changes that affect farm households and lifestyles, entrepreneurial development, and business-like approach to agriculture can provide the needed impetus for a new agricultural culture in Ghana. In addition, the symbolic importance of agriculture in its various manifestations (such as a status symbol) and for the various "national culture" actors, and how policy facilitates the shaping of these perceptions to understand the consequences for such symbolic importance, provide avenues for improved interaction between agriculture and its cultural environment.

\section{Conclusion}

This paper provides a review of Ghana's agricultural development process since independence in 1957, making reference to the key development issues during the colonial era. A historical survey of various economic and agricultural policies pursued by various governments and how they have impacted on agriculture is presented. Also, based on available information in the literature and analysis done under the roles of agriculture (ROA) project by Food and Agriculture Organization, an assessment of the policy effects on the various roles of agriculture, particularly during the 1990s, is presented. The performance of the agricultural sector has generally directed the overall economic performance since independence. Economic policies have had important implications for the roles of agriculture in the socio-economic development of Ghana because of agriculture's dominance of the economy. Past agricultural policies have ranged from the socialist model of the 1960s to a liberalized market of the 1980s and 1990s, with differing effects on the roles of agriculture. In particular, the externalities generated by agriculture in response to the policy changes have varied across different policy regimes, and trade-offs have emerged among the different roles.

\section{References}

Aneani, F. (1995). Commodity Concentration and Export Earnings Instability: A case of Ghana's Agricultural Exports. An MPhil. Thesis submitted to the Department of Agricultural Economy and Farm Management, Faculty of Agriculture, University of Ghana, Legon.

Aryeetey, E. (1996). The Formal Financial Sector in Ghana after the Reforms. Working Paper No. 86. London. Overseas Development Institute.

Food and Agriculture Organization of the United Nations (FAO). (2004). Socio-Economic Analysis and Policy Implications of the Roles of Agriculture in Developing Countries. Research Programme Summary Report 2004. Rome.

Institute of Statistical, Social and Economic Research (ISSER). (2000). The State of the Ghanaian Economy. University of Ghana, Legon.

Kuwornu, J. K. M., Abboah, R., Amegashie, D. P. K. \& Kuiper, W. E. (2009). Econometric Analysis of Marketing Costs: A Case Study. Journal of Food Distribution Research, 40(1), 83-89.

Kuwornu, J. K. M., Demi M. S. \& Amegashie, D. P. K. (2013). Comparative Analysis of Food Security Status of Farming Households in the Coastal and the Forest Communities of Central Region of Ghana. Asian Journal of Empirical Research, 3(1), 39 - 61.

Leith, J. C. (1971). Export Concentration and Instability: The case of Ghana. The Economic Bulletin of Ghana, 1, 45-55.

Ministry of Food and Agriculture (MoFA). (1997). Agriculture in Ghana: Facts and Figures, PPMED, Accra. Ministry of Food and Agriculture (MoFA). (2002). Agriculture in Ghana: Facts and Figures, PPMED, Accra. Ministry of Food and Agriculture (MoFA). (2006). Agriculture in Ghana: Facts and Figures, PPMED, Accra. Ministry of Food and Agriculture (MoFA). (2007). Agriculture in Ghana: Facts and Figures, PPMED, Accra. 